Please do not remove this page

RMIT

UNIVERSITY

\title{
Exploring the impact of mobile money services on marketing interactions in relation to consumer well-being in subsistence marketplace - Lessons from rural Cambodia
}

Fang, Jeff; Russell, Roslyn; Singh, Supriya

https://researchrepository.rmit.edu.au/esploro/outputs/9921859646001341/filesAndLinks?institution=61RMIT_INST\&index=null

Fang, J., Russell, R., \& Singh, S. (2014). Exploring the impact of mobile money services on marketing interactions in relation to consumer well-being in subsistence marketplace - Lessons from rural Cambodia. Journal of Marketing Management, 30(5-6), 445-475.

https://doi.org/10.1080/0267257X.2014.884619

Document Version: Accepted Manuscript

Published Version: https://doi.org/10.1080/0267257X.2014.884619

Repository homepage: https://researchrepository.rmit.edu.au

(c) 2014 Westburn Publishers Ltd.

Downloaded On 2023/04/26 23:09:28 +1000 
Thank you for downloading this document from the RMIT Research Repository.

The RMIT Research Repository is an open access database showcasing the research outputs of RMIT University researchers.

RMIT Research Repository: http://researchbank.rmit.edu.au/

\section{Citation:}

Fang, J, Russell, R and Singh, S 2014, 'Exploring the impact of mobile money services on marketing interactions in relation to consumer well-being in subsistence marketplace Lessons from rural Cambodia', Journal of Marketing Management, vol. 30, no. 56, pp. 445-475.

See this record in the RMIT Research Repository at:

https://researchbank.rmit.edu.au/view/rmit:24513

Version: Accepted Manuscript

Copyright Statement: (c) 2014 Westburn Publishers Ltd.

Link to Published Version:

http://dx.doi.org/10.1080/0267257X.2014.884619 


\title{
Exploring the impact of mobile money services on marketing interactions in relation to consumer well-being in subsistence marketplaces - Lessons from rural Cambodia
}

\author{
Jeff Fang, Roslyn Russell \& Supriya Singh \\ RMIT University, Australia
}

\begin{abstract}
About the authors
Jeff Fang is currently a PhD candidate in the School of Economics, Finance and Marketing, RMIT University, Melbourne Australia. With about 10 years of industry experience in Cambodia, Australia, Singapore and Vietnam, Jeff has worked on various financial services projects relating to operational and technology best practices. Jeff is also involved in industry research projects relating to financial literacy and microfinance. His current research interests include financial capability/well-being (including financial literacy), consumer well-being, mobile money services and microfinance services.
\end{abstract}

Corresponding author: Jeff Fang, School of Economics, Finance \& Marketing, RMIT University, GPO Box 2476, Melbourne, Victoria 3001, Australia

T +61399251116

E jeff.fang@rmit.edu.au

Roslyn Russell is Professor of Microfinance in the School of Economics, Finance and Marketing, RMIT University, Melbourne Australia. Roslyn specialises in evaluating microfinance programs for financial institutions, government departments and Non-Government Organisations.

T +6139925 5187
E roslyn.russell@rmit.edu.au

Supriya Singh is Professor, Sociology of Communications at the Graduate School of Business and Law, RMIT University, Melbourne Australia. She co-leads the Community Sustainability Program of the Global Cities Research Institute and is a senior project leader for RMIT Business' research with the Smart Services Co-operative Research Centre. Supriya brings together expertise in the sociology of money and banking; globalization, migration and remittances; and the use of new communications technologies within the social and cultural context. She was awarded the Jean Martin Prize in 1995 for the best Sociology PhD thesis in Australia, 1993-1995, by the Australian Sociological Association. Her books include Globalization and Money: A Global South Perspective (2013; Marriage Money: The Social Shaping of Money in Marriage and Banking (1997); The Bankers (1991); The First 25 Years - Bank Negara Malaysia (1984); and On the Sulu Sea (1984).

T +61399251327

E supriya.singh@rmit.edu.au 


\section{Exploring the impact of mobile money services on marketing interactions in relation to consumer well-being in subsistence marketplaces - Lessons from rural Cambodia}

Abstract - The mobile phone has increasingly become a channel for providing access to formal financial services. There is a need to understand how financial service offerings increasingly accessed through mobile phones impact marketing interactions, specifically marketing exchange activities and social network relationships, to enhance consumer well-being in subsistence marketplaces. Through interviews and contextualised observational research in rural Cambodia, findings reveal the impacts of mobile money services on marketing interactions in relation to consumer well-being can be categorised at two distinct levels. The first level impact is the actual physical money transfer transactions as part of the marketing exchange activities which leads to the second level impact on the social network relationships at interpersonal, social group and cultural levels. Drawing from these insights, policy-makers and industry stakeholders can formulate strategies and develop innovative service offerings through mobile phone technology to enhance consumer well-being in subsistence marketplaces.

Summary statement of contribution - This paper contributes to knowledge on the nature of marketing interaction disparities. In particular it expands the understanding of marketing exchange activities through money transfer transactions and social network relationships, and provides insights on the impact of the delivery of financial services through mobile phones (mobile money services) on these marketing interactions in relation to consumer well-being in subsistence marketplaces.

Keywords - Subsistence Marketplaces, Consumer Well-Being, Marketing Exchanges, Social Network Relationships, Financial Inclusion, Mobile Money, Mobile Phones, Cambodia 


\section{Introduction}

This paper explores the impact of mobile money services on marketing interactions in relation to consumer well-being (CWB) in subsistence marketplaces using the example of mobile money users in rural Cambodia. There is a need to better understand how financial services offered to subsistence consumers can help enhance CWB (Anderson et al., 2013). Hence, this paper responds to this call and contributes to the research on subsistence marketplaces and the nature of marketing interaction disparities. It specifically deals with marketing exchange activities using money transfer transaction exchanges and social network relationships, and the impact of financial service offerings through mobile phones (mobile money services) on these marketing interactions in relation to CWB.

By the end of 2011, about 55\% of the global adult population (total population in 2011 was about 6.8 billion) live in rural areas with few or no opportunities to access formal financial services accounts to save, borrow or transact (Demirguc-Kunt \& Klapper, 2012; WBG, 2012a). Subsistence consumers typically have few or no opportunities to grow their income, access formal education, basic amenities and formal financial services (Viswanathan \& Rosa, 2007; Weidner, Rosa, \& Viswanathan, 2010). Mobile money services, or accessing financial services through mobile phones, can potentially impact CWB by increasing opportunities to help subsistence consumers grow their household income, accumulate their asset base, smooth expenditure in the event of erratic cash inflows, manage family well-being and improve their resilience by protection against circumstantial emergency shocks and vulnerabilities (Chopra, Dwivedi, \& Sherry, 2013; Morawczynski, 2009). 
Subsistence consumers display great interest and capacities in adopting technological products and services to empower themselves and significantly influence their day-to-day lives (Trujillo, Barrios, Camacho, \& Rosa, 2010). Global mobile phone subscriptions accelerated from 2.2 billion in 2005 to about 6 billion in 2011, reaching 86 per cent of the total global population and 75 per cent of the developing countries' population (ITU, 2013). The mobile phone has increasingly become a channel for providing access to formal financial services in subsistence marketplaces, hence defined in this study as "Mobile Money Services".

Consumers in developed countries typically have access to financial services due to the already established and readily accessible financial infrastructure systems (Flood, West, \& Wheadon, 2013). As such, mobile money adoption in developed countries is low as most consumers already have access to formal financial services with the mobile phone being just another channel to incrementally extend the convenience of accessing already existing service offerings by financial institutions (Flood, et al., 2013; Mauree \& Kohli, 2013). On the contrary, mobile money services form a crucial link to the formal economy in developing countries for subsistence consumers by increasing levels of financial inclusion and overcoming financial infrastructure systems inefficiencies (Flood, et al., 2013). This is made possible as mobile money utilises the branchless banking concept whereby subsistence customers without bank accounts can access financial services through technology and local non-bank retail agents within nearby vicinities (Singh \& Shelly, 2010).

Mobile money services in the subsistence marketplace context include (1) Person-toperson funds transfer (domestic and international remittances); (2) Person-to-business or business-to-business payments, (3) Mobile banking through which customers can access their bank accounts, pay bills, or deposit and withdraw funds; and (4) Mobile phone credits top-up and 
mobile phone credit air-time transfers (Morawczynski, 2009; Tobbin, 2011). By May 2013, over 160 mobile money projects were deployed in more than 70 emerging countries (GSMA, 2013b) with the Philippines being the first to roll out the first known sustainable mobile money service (Smart Money) and Kenya's M-PESA being currently the most well-known mobile money service (Donavan, 2012; Heyer \& Mas, 2010; Morawczynski, 2009).

Some research studies on the impacts of mobile money services have been conducted in subsistence marketplaces. For example Morawczynski (2009) concluded that the mobile money service in Kenya called M-PESA reduced residents' vulnerability through solicitation of financial assets and maintaining social networks. Morawczynski (2011) further highlighted that subsistence consumers combined individual savings mechanisms for different needs as a savings portfolio and M-PESA provided a complementary platform to mobilizing this savings portfolio whereby these various savings mechanisms can be safely and easily accessed. This further motivates this research to expand the knowledge of mobile money services and its effects on CWB in a wider context of subsistence marketplaces.

Cambodia is regarded as a "low-income" country with a per capita gross national income (GNI) of US\$820, compared to an average GNI of US\$4,200 in the East Asia and Pacific region, US\$1,530 in "lower middle income" India and US\$48,000 in "high income" USA (WBG, 2012b). Cambodia has a population of about 14.5 million with about 20 per cent (about 3 million) living in urban areas and 80 per cent (about 11.5 million) living in rural areas (WBG, 2012b). Furthermore, only 2.4 per cent of the adult population living in rural areas have formal bank accounts compared to 10.2 per cent of the adult population living in urban areas (WBG, 2012a, p. 40). Rural employment is predominantly agrarian-based with approximately 73 per cent of workers being engaged in agriculture, forestry and fisheries (NIS, 2010, 2012). 
Formal banking services offered by banks and microfinance institutions in Cambodia are not commonly available with its penetration rate reaching only about 90 per 1000 people (NBC, 2010). In 2011, it was estimated that 96 per cent of the Cambodian adult population (about 9.4 million adults) lacked a bank account to access formal financial services (Demirguc-Kunt \& Klapper, 2012; WBG, 2012a, p. 40; 2012b).

However, Cambodian mobile phone subscriptions have grown from about 660,000 in 2004 to about 20 million in mid-2012 (BMI, 2012; MPTC, 2012). Mobile phone network penetration rate is about 96 per 100 people with mobile phone network affordability estimated at about US\$8 per month (WBG, 2013, p. 49). Local and foreign-invested telecommunications firms have taken steps to enter the Cambodian market and there are currently eight mobile phone operators in Cambodia with their combined network coverage readily accessible to about 99 per cent of the total population (GSMA, 2013a; WBG, 2013, p. 49). This shows the mobile phone network is readily available to a majority of subsistence consumers in Cambodia. It also demonstrates mobile phones being more common in places where formal banking services are less available.

In 2008, a mobile money service provider called WING Money Cambodia (WING) was launched in Cambodia to provide access to basic financial services through mobile phones. By the end of 2012, WING had over 400,000 registered mobile money account users with services available in all of Cambodia's 24 provinces. By 2012, more than 22 million mobile financial transactions had been processed with the total transaction volume of about US\$287 million (WING, 2013a, 2013b). Cambodia is thus a suitable example to better understand the role of mobile money as a financial service offering in a subsistence marketplace. 
Findings primarily from interviews and contextualised observational research carried out in rural Cambodia between July 2011 and September 2011 were used to determine how subsistence consumers experience mobile money services and the impacts on marketing interactions in relation to CWB. The literature review covers subsistence marketplaces and CWB followed by an overview on marketing interactions with a specific focus on marketing exchanges and social network relationships. Building from these concepts with links to the literature on mobile phones and access to financial services will set the appropriate platform for this paper. The paper then covers the methods used for collecting data in rural Cambodia and the subsequent findings followed by a discussion. The paper then gives the conclusions and possible future research directions.

\section{Subsistence marketplaces and consumer well-being}

"Subsistence" defines the survivalist consumption needs of low to extremely low-income people while "marketplaces" focuses on transactional exchanges and relationships which consumers rely on to satisfy livelihood needs (Viswanathan, Sridharan, Ritchie, Venugopal, \& Jung, 2012). Over 4 billion subsistence consumers (termed the "bottom of the pyramid") live in subsistence marketplaces mostly in Africa, Asia and Latin America with an estimated annual income below USD\$3,000 in local purchasing power (Hammond, Kramer , Katz, Tran, \& Walker, 2007; Viswanathan \& Rosa, 2007). Of these, about 1.4 billion live on less than USD $\$ 1.25$ a day (IFAD, 2010, p. 16). 
Viswanathan, Seth, Gau, and Chaturvedi (2007) describe a typical subsistence marketplace constituent as an individual and/or family household residing in sub-standard accommodations with uncertainty and little control over their daily life activities/processes. Furthermore they have few or no opportunities to grow their income, access formal education, basic amenities and formal financial services (Viswanathan \& Rosa, 2007; Weidner, et al., 2010).

Consumer Well Being (CWB) can be conceptualised as aligning individual and societal needs (i.e. physical, psychological, economic, social) in relation to consumption (Burroughs \& Rindfleish, 2011; Pancer \& Handelman, 2012). Anderson, et al. (2013) further termed this as eudaimonic well-being which highlights dimensions like access, literacy, consumer involvement, respect, support and social networks at individual, collective and ecosystem levels. These same orientations are reflected by research studies that helped increase the understanding and enhancement of CWB in subsistence marketplaces. For example, research studies have focused on increasing marketplace literacy levels through designing innovative education programs for low-literate subsistence consumers and entrepreneurs (Bello-Bravo, Diaz, Venugopal, Viswanathan, \& Pittendrigh, 2010; Rosa, 2012; Viswanathan, Gajendiran, \& Venkatesan, 2008; Viswanathan, Sridharan, Gau, \& Ritchie, 2009). Research has also highlighted innovative ways of improving product development processes and developing effective marketing management strategies to successfully engage consumers in subsistence marketplaces (Viswanathan \& Rosa, 2007; Viswanathan, et al., 2007; Weidner, et al., 2010). Research has also focused on increased understanding of marketing interactions through marketing exchanges and social network relationships (Sridharan \& Viswanathan, 2008; Viswanathan, 2007; Viswanathan, Rosa, \& Ruth, 2010; Viswanathan, Sridharan, \& Ritchie, 2010; Viswanathan, et al., 2012). 
This paper builds from the eudaimonic well-being dimensions of CWB combined with insights from marketing interactions to form the conceptual base structure in exploring how mobile money services affect the marketing exchanges and social network relationships in relation to CWB in subsistence marketplaces.

\section{Marketing interactions in subsistence marketplaces}

\section{Marketing exchanges in subsistence marketplaces}

The notion of exchange is widely accepted as the central theme of marketing that encompass customer behaviours, channels and competitors (Lusch, Brown, \& Brunswick, 1992). Bagozzi (1975) illustrates three types of exchange paradigms - restricted, generalized, and complex - with most marketing exchanges being generalized (at least three actors benefiting one another only indirectly) and complex (at least three actors with at least one direct exchange with mutual relationships). Lusch, et al. (1992) further contend that marketing exchanges can occur internally to satisfy needs within the organization and externally to satisfy needs outside the organization. However, existing views of exchange paradigms are informed by phenomena established in formal economies through governing rules, formalised contracts and enforced policy regulations (Viswanathan, et al., 2012). Marketing exchanges in the subsistence context focus instead on a parallel informal economy where livelihood needs are not adequately met by formal marketing exchange settings (Viswanathan, et al., 2012) and governed with little or no legally enforced regulations and protections (Chen, 2007). 
When examining the marketing exchange activities of subsistence consumers in South India, Viswanathan (2007) highlighted four key characteristics of product and market interactions in subsistence marketplaces and singled out the aspects of day-to-day life as having uncertainty, lack of control and complexity. In characterizing the interactions occurring within the marketing exchange, Viswanathan, et al. (2012) further identified three specific exchange elements that are fluid, constantly customized and comprised of highly responsive transactions from a social capital perspective. The nature of marketing exchange activities in subsistence contexts (Viswanathan, 2007) can also include the actual physical money transfer transactions among subsistence consumers, defined conceptually as a monetary marketing exchange using money as a medium of exchange (Duffy \& Ochs, 1999; Kiyotaki \& Wright, 1989).

By building conceptually from previous studies on marketing exchanges within subsistence marketplaces, this paper further explores the practice of the actual physical money transfer transaction and identifies the impacts of mobile money services on the monetary marketing exchange.

\section{Social network relationships in subsistence marketplaces}

The concept of marketing interactions also draws from on-going discourses on social networks through social capital theory, broadly defined as encompassing the norms and networks to facilitate people's collective action for mutual benefits (Woolcock, 1998).

Studies on social networks have shown the key role of embedded social networks within marketing interactions as being characterized by deep social relationships to help consumers and 
entrepreneurs steer through subsistence marketplaces (Sridharan \& Viswanathan, 2008; Viswanathan, Sridharan, et al., 2010).

Recent research studies have also highlighted the impact of mobile phone usage on social networks. For example, Smith and Spence (2011) suggested the mobile phone as a platform for information sharing and connectedness to enable/strengthen social, economic and governance networks. In the context of subsistence marketplaces, Smith and Spence (2011) noted further the use of mobile phones for maintaining (1) family and social relations, (2) the ability to act in an emergency and (3) the efficiency of daily activities.

In another study, Donner (2006) determined that Rwandan micro-entrepreneurs use mobile phones to increase the frequency of contact with friends, family and existing business networks and to establish new connections with business partners, suppliers, and customers. Mobile phones also helped subsistence marketplace producers/traders in India respond quickly to market demand, help coordinate supply and demand as well as provide free access to price information for demand catering in undersupplied markets (Abraham, 2007).

Consumer behaviour within social network relationships are also guided by cultural customs, values, and beliefs (Arnould \& Wallendorf, 1994). Within these social network relationships exist traditional cultural values and social norms rich in cultural meaning, practices and obligations (Sridharan \& Viswanathan, 2008) to honour and maintain social relations and family ties (Ruth \& Hsiung, 2007). Gift giving is one such cultural example that promotes ties and bonding between individuals (Joy, 2001). Gift giving binds personal relationships in daily life as well as to harmonise and enhance interpersonal social relationships (Tynan, Teresa Pereira Heath, Ennew, Wang, \& Sun, 2010; Wong, Hogg, \& Vanharanta, 2012). Craig and Douglas 
(2006) further assert that each culture develops its own gift-giving practices consistent with the social network relationships within the culture.

In Cambodia, social networks are valued as "khnang" ("strong back") or connections and networks in the "string" ("khsae") of patronage relationships (linking ordinary villagers or subsistence consumers with higher status individuals) used to access opportunities, to help grow rural household wealth and help secure favourable outcomes in local decision-making, conflicts and legal disputes (FitzGerald, Suvannariddhi, \& Suphal, 2007). Traditional gift giving in Cambodia can be viewed as a contemporary practice for seeking economic opportunities and gaining protection by attaching themselves to political patrons or higher status individuals with influential power and respect (Ledgerwood, 2012). Hence, gift receivers as well as higher status individuals gain personal merits through securing favours for the gift givers (Hughes, 2006). Furthermore, the gift givers continuously received a "khsae" network of favourable support or protection from these gift receivers (Hughes, 2006).

However, the idea of gift giving for this paper focuses on Cambodian traditional festivals which involves meeting social obligations and maintaining or building resilient social networks to bind subsistence communities (Ledgerwood, 2012). Furthermore, gift giving is also considered an appropriate social practice for a social gathering or celebration where the gifts do not have to be elaborate or expensive (North, 2008) but play an important role in confirming and establishing social network relationships (Davis, 2009). Many subsistence Cambodians have few material possessions within their own lifetimes and gifts in the form of cash are extremely important to enable asset-building (North, 2008). 
Despite increased number of discourses within the broad social capital literature, the nature of marketing interactions remain under-researched in the context of subsistence marketplaces and is therefore an important area for this paper to further reflect the subsistence level and informal economy setting (Viswanathan, et al., 2012). This paper also builds from the insights of understanding cultural values and social norms within social networks to explore how mobile money services subsequently impact the various cultural meanings, practices and obligations, including the gift giving and other cultural practices, consistent within these social networks.

\section{Mobile money services in subsistence marketplaces}

Jack and Suri (2011) estimated that in 2009 more than two-thirds of Kenyan households had at least one member accessing M-PESA's service. Morawczynski (2009) concluded that M-PESA was used for the solicitation of financial assets. For example, urban migrants used M-PESA as a safer, easier and more convenient way of mobilizing financial assets and sending money back to rural families to help them recover from financial stresses and shocks especially during periods of ethnic violence (Morawczynski, 2009). Morawczynski (2009) further observed that while the money transfer transactions symbolised an act of the sender's social obligation to send money back home and maintain social links with rural family members/relatives, M-PESA interestingly weakened social network relations between the sender (urban migrants) and the receiver (rural family members/relatives) due to urban migrants making less visits back home. 
Morawczynski (2011) asserts that poor people learn to associate individual savings instruments with particular savings needs and hence utilise different portfolios to meet their unique savings requirements. M-PESA then becomes a platform where poor people can easily and conveniently access and mobilise these various savings portfolios through a single mobile phone (Morawczynski, 2011).

Most research studies on mobile money services have focused on consumer adoption perspectives, technology design improvements and business-driven models (Dahlberg, Mallat, Ondrus, \& Zmijewska, 2008; Dewan, 2010; Duncombe \& Boateng, 2009) but the impacts of this innovation on consumers in relation to consumer well-being remain under-researched. The under-researched areas also include (1) geographical areas, particularly for Latin America, China and Southeast Asia, (2) conceptual approaches, especially in needs and impact research, and (3) methodological approaches, especially in-depth qualitative studies (Dewan, 2010; Diniz, Albuquerque, \& Cernev, 2011; Donner \& Tellez, 2008; Duncombe \& Boateng, 2009).

Each society and culture is unique with varied social and cultural needs. Building from previous studies, this paper helps to conceptualise mobile money services as a mechanism for mobilising financial assets towards CWB. Importantly, it illustrates how mobile money services, as a mechanism, impacts the well-being and daily activity processes of individual, community and business lives. 


\section{Methodology}

\section{Methodological framework}

The Most Significant Change (MSC) methodological framework was used in this research. This involved the collection of significant change stories emanating from the field or micro level to describe the impacts of an intervention on people's lives. Davis and Dart (2005) asserted that the MSC framework suited evaluation programs or projects, regardless of nationalities or cultures, that were participatory in ethos and/or focused on social change.

The MSC methodology acted as an interface between academic research, professional practice and the participants involved in the research (McDonald, Bammer, \& Deane, 2009). Hence the MSC methodological framework was intended to further strengthen academic rigour in systematically identifying and giving value to any changes due to the phenomenon but were nevertheless significant impacts for those involved (Wrigley, 2006).

\section{Methods of inquiry}

The field work was conducted between July and September 2011 in Cambodia. Access to mobile money service customers was provided through collaboration with WING, the leading mobile money services provider in Cambodia. Primary data came from face-to-face, audio-recorded semi-structured interviews with selected WING customers and observational research was conducted in six rural provinces to capture in context, customer perceptions/experiences before and after using mobile money services. 
Interviews can be described as a conversation focusing on capturing the essence, meaning or significance of the experiences of people using mobile money services within their world (Seidman, 2006). Kvale (2007) further highlighted that interview conversations allow researchers to learn about an individual's experiences, feelings, hopes, views and opinions expressed in their own words.

To enable a more theory-based approach to the interview process and to maintain the consistency of the interview sessions, an interview schedule was developed based upon an adapted version of the Three-Interview Series model (Schuman, 1982; Seidman, 2006). This model focuses on life history, details of the experience and meaning of the experience. As the interview session was designed to be fairly informal, open-ended and conversational, the order of sequence for the interview questions was flexible and follow-up questions were covered for clarification purposes.

Contextual observational research complemented the primary interview data. Besides providing context on different heterogeneous settings (understanding a cluster of groups or categories) rather than just one homogeneous setting (focussing on one group or category like farmers or small business owners), the researchers could immerse into the world of mobile money services. The researchers could see how mobile money services were used by different people in different social settings in their daily life processes, whether they were individuals, families, communities or business owners (Angrosino, 2007). During the course of observation, the research also uncovered new themes regarding the potential impacts as well as other applications of mobile money services in rural areas and this was subsequently followed up with conversations and queries with interviewees to deepen the understanding of the interactions and processes involved. 


\section{Sampling}

This research followed the guidance of Flick $(2009$, p. 121) that sampling in qualitative research "proceeds according to the relevance of cases instead of their representativeness" in determining how the people to be studied are selected. Hence, this research conducted interviews that were sufficient to gain an understanding of the phenomena based on (1) Sufficiency to reflect the range of participants and sites in making up the population and (2) Information saturation due to repetition of same information among informants (Seidman, 2006):

In total, this research had a sample size of 20 males and 15 females as shown below in Table 1: 
Table 1 Informant Background Information

\begin{tabular}{|c|c|c|c|c|c|}
\hline Informant $^{\mathrm{a}}$ & $\begin{array}{l}\text { Occupation/Type of Business } \\
\text { Activity }\end{array}$ & Gender & Age & $\begin{array}{l}\text { Marital } \\
\text { Status }\end{array}$ & Education Level \\
\hline Sally & Youth Salesgirl & Female & 19 & Single & High School \\
\hline Caleb & Mobile Phone Shop Owner & Male & 27 & Married & High School \\
\hline Michael & Money Transfer Agent & Male & 24 & Married & High School \\
\hline Katrina & Government Officer & Female & 29 & Divorced & High School \\
\hline Shirley & $\begin{array}{l}\text { Mobile Phone/Stationery Shop } \\
\text { Owner }\end{array}$ & Female & 25 & Married & High School \\
\hline Valerie & Vegetable Seller & Female & 32 & Married & No formal education \\
\hline Pat & Photoshop Owner & Female & 28 & Married & High School \\
\hline Kelvin & Government Officer & Male & 32 & Married & High School \\
\hline Charlie & Border Immigration Policeman & Male & 49 & Married & High School \\
\hline Gordon & $\begin{array}{l}\text { Grocery Shop Owner (Floating } \\
\text { Village) }\end{array}$ & Male & 29 & Married & High School \\
\hline Harry & Soldier & Male & 36 & Married & High School \\
\hline Jasmine & Student & Female & 19 & Single & High School \\
\hline Vince & Drinks Stall Owner & Male & 31 & Married & High School \\
\hline Nick & Farmer & Male & 47 & Married & High School \\
\hline Daniel & Youth Salesman & Male & 23 & Single & High School \\
\hline Lynn & Student & Female & 19 & Single & High School \\
\hline William & $\begin{array}{l}\text { Mobile Phone Shop Owner (Floating } \\
\text { Village) }\end{array}$ & Male & 20 & Single & High School \\
\hline Susan & Hairdresser & Female & 32 & Married & High School \\
\hline Jim & Telephone Operator Salesman & Male & 27 & Single & High School \\
\hline Larry & Work Employee & Male & 38 & Married & High School \\
\hline Eugene & Student & Male & 20 & Single & High School \\
\hline Diane & Mobile Phone Shop Owner & Female & 22 & Married & High School \\
\hline
\end{tabular}




\begin{tabular}{|l|l|l|l|l|l|}
\hline Informant & $\begin{array}{l}\text { Occupation/Type of Business } \\
\text { Activity }\end{array}$ & Gender & Age & $\begin{array}{l}\text { Marital } \\
\text { Status }\end{array}$ & Education Level \\
\hline Sylvia & Book and Stationery Shop Owner & Female & 29 & Married & High School \\
\hline Barry & Grocery Shop Owner & Male & 26 & Married & High School \\
\hline John & Locksmith Shop Owner & Male & 26 & Married & High School \\
\hline Pamela & $\begin{array}{l}\text { Money Transfer/ Money Exchange } \\
\text { Shop Owner }\end{array}$ & Female & 27 & Single & High School \\
\hline Mary & Youth Salesgirl & Female & 21 & Single & High School \\
\hline Amy & Liquor and Drinks Shop Owner & Female & 32 & Married & High School \\
\hline Matt & Liquor and Drinks Shop Owner & Male & 19 & Single & High School \\
\hline Lisa & Student & Female & 19 & Single & High School \\
\hline Cheryl & Meat Seller & Female & 20 & Single & High School \\
\hline Alvin & Monk & Male & 19 & Single & High School \\
\hline Peter & Mobile Phone Shop Owner & Male & 31 & Single & University \\
\hline Ricky & Soldier & Male & 24 & Single & High School \\
\hline Mark & Student & Male & 22 & Single & High School \\
\hline
\end{tabular}

a All informants' names are pseudonyms to protect anonymity. 


\section{Data analysis}

The interview scripts were translated from the Cambodian Khmer language to English. Data analysis was done through documentation, categorization and interpretation. Documentation involves transcribing the data and recording the attributes of the data such as the interview date, location and some key information on the participant. Categorization involves data coding in a structured way to identify or record one or more data items, text or passages that exemplifies similar phenomenon, ideas, explanations or activities. Interpretation involves linking the coded data back to a point of reference in the literature in order to test the emerging understanding or search for alternative explanations (Flick, 2009; Gibbs, 2007; Marshall \& Rossman, 1999).

\section{Findings}

Our findings reveal the impacts of mobile money services on marketing interactions in relation to consumer well-being at two distinct levels. The first level impacts involve the marketing exchanges, more specifically around the safety, convenience and speed of the money transfer transaction exchanges. The three themes identified in this first level are (1) Enhancing accessibility, (2) Reducing task complexity and (3) Elimination of intermediation. Table 2 summarises these identified themes before and after using mobile money services. The second level impacts are on the social network relationships resulting from the change at the first level impacts on the actual physical money transfer transaction. The three themes identified in the second level are (1) Interpersonal level, (2) Social group level and (3) Cultural level. Table 3 summarises these identified themes before and after using mobile money services. 
Table 2 Summary of First Level Impacts of Mobile Money Services on Marketing Exchanges (Actual Physical Safety, Convenience and Speed of Money Transaction)

\begin{tabular}{|c|c|c|}
\hline $\begin{array}{l}\text { Key themes } \\
\text { identified }\end{array}$ & Before using mobile money services & After using mobile money services \\
\hline $\begin{array}{l}\text { Enhancing } \\
\text { accessibility }\end{array}$ & $\begin{array}{l}\text { Lack of products for physiological, } \\
\text { personal or business needs available } \\
\text { in local areas } \\
\text { Inconvenient way of transferring money } \\
\text { to family and friends to help } \\
\text { purchase }\end{array}$ & $\begin{array}{l}\text { Products previously not available can } \\
\text { now be purchased from other } \\
\text { locations } \\
\text { Faster and more convenient to } \\
\text { transfer money to family and } \\
\text { friends to help purchase }\end{array}$ \\
\hline $\begin{array}{l}\text { Reducing task } \\
\text { complexity }\end{array}$ & $\begin{array}{l}\text { Spent time queuing up and completing } \\
\text { complicated money transfer service } \\
\text { documentation. } \\
\text { Proof of identification from sender and } \\
\text { receiver to complete the transaction } \\
\text { also required }\end{array}$ & $\begin{array}{l}\text { A simplified and less complex } \\
\text { procedure of initiating the mobile } \\
\text { money transfer service without } \\
\text { required identification } \\
\text { System issued } 8 \text { digit code given to } \\
\text { the receiver to collect the money } \\
\text { at their own convenience }\end{array}$ \\
\hline $\begin{array}{l}\text { Elimination of } \\
\text { intermediation } \\
\text { (Bus, truck, } \\
\text { boat and taxi } \\
\text { drivers) }\end{array}$ & $\begin{array}{l}\text { Other scheduling priorities and the } \\
\text { uncertainty of guessing when the } \\
\text { intermediaries were readily available } \\
\text { and where to find them } \\
\text { Transferring money took a long time } \\
\text { due to the long road travel } \\
\text { Fear of money stolen or lost through } \\
\text { these intermediaries resulting in } \\
\text { correct amount products/goods } \\
\text { received }\end{array}$ & $\begin{array}{l}\text { Received money almost } \\
\text { instantaneously through their } \\
\text { mobile money account or at the } \\
\text { nearest mobile money collection } \\
\text { point } \\
\text { Timing and scheduling became more } \\
\text { certain and controlled by sender } \\
\text { and receiver }\end{array}$ \\
\hline
\end{tabular}


Table 3 Summary of Second Level Impacts of Mobile Money Services on Social Network Relationships

\begin{tabular}{|c|c|c|}
\hline $\begin{array}{l}\text { Key themes } \\
\text { identified }\end{array}$ & Before using mobile money services & After using mobile money services \\
\hline $\begin{array}{l}\text { Interpersonal } \\
\text { level }\end{array}$ & $\begin{array}{l}\text { Physical and emotional frustrations } \\
\text { encountered due to unmet needs and } \\
\text { miscommunications resulting in } \\
\text { strained relationships }\end{array}$ & $\begin{array}{l}\text { Closer and better relationships among } \\
\text { personal or business social } \\
\text { networks due to absence/removal } \\
\text { of physical and emotional } \\
\text { frustrations }\end{array}$ \\
\hline \multirow[t]{3}{*}{$\begin{array}{l}\text { Social group } \\
\text { level }\end{array}$} & $\begin{array}{l}\text { Social group activity i.e. savings group } \\
\text { not available locally and lack } \\
\text { opportunity to participate }\end{array}$ & $\begin{array}{l}\text { Opportunity given to participate } \\
\text { remotely in a social group activity } \\
\text { regardless of location }\end{array}$ \\
\hline & $\begin{array}{l}\text { Difficult, expensive and inconvenient to } \\
\text { send money home to support poor } \\
\text { low-income family members' living } \\
\text { expenses and other circumstantial } \\
\text { needs }\end{array}$ & $\begin{array}{l}\text { Cheaper, faster and more convenient } \\
\text { to transfer to family members to } \\
\text { support their living expenses and } \\
\text { other circumstantial needs } \\
\text { Extra money sent back due to } \\
\text { reduced transfer fees }\end{array}$ \\
\hline & $\begin{array}{l}\text { Transferring money takes too long and } \\
\text { unable to respond quickly to } \\
\text { emergency needs }\end{array}$ & $\begin{array}{l}\text { Faster and more effective in } \\
\text { transferring money resulting in } \\
\text { immediate response to emergency } \\
\text { needs }\end{array}$ \\
\hline \multirow[t]{4}{*}{ Cultural level } & $\begin{array}{l}\text { Difficult and inconvenient to send } \\
\text { "gift" money to family }\end{array}$ & $\begin{array}{l}\text { Faster and more convenient to send } \\
\text { "gift" money to family }\end{array}$ \\
\hline & $\begin{array}{l}\text { Work commitments resulting in not } \\
\text { being able to travel back for family } \\
\text { reunion and fulfilling } \\
\text { religious/cultural obligations }\end{array}$ & $\begin{array}{l}\text { Transfer money to family faster to } \\
\text { purchase products/materials as } \\
\text { part of pre-festival preparation } \\
\text { activities }\end{array}$ \\
\hline & Gifts in cash form to bless recipients & $\begin{array}{l}\text { Ensured religious/cultural obligations } \\
\text { being met while not being there } \\
\text { Easy and faster topping up of mobile } \\
\text { phone credits as a modern way to } \\
\text { bless recipients and affirming } \\
\text { friendships }\end{array}$ \\
\hline & $\begin{array}{l}\text { Monks seen topping up mobile phone } \\
\text { credits at shops misunderstood for } \\
\text { contradicting religious beliefs }\end{array}$ & $\begin{array}{l}\text { Monks storing donations safely and } \\
\text { easily topping up mobile phones to } \\
\text { contact families without getting } \\
\text { misunderstood }\end{array}$ \\
\hline
\end{tabular}




\section{First level impacts of mobile money services on marketing exchanges (actual physical safety, convenience and speed of money transaction)}

\section{Enhancing accessibility}

Informants described the lack of products/materials accessible in their local districts which might affect their physiological, personal or business needs. These materials included farming or business materials, clothes, traditional or special food ingredients, personal accessories for consumption use. Using existing money transfer services like buses or taxis to send to families or friends to help purchase materials took a lengthy time and became inconvenient. Mobile money services enhanced the accessibility by enabling informants to conveniently transfer money to family members or friends in other distant localities to help purchase the required products.

John is a 26 year old rural locksmith and sole financial provider to his family including his 22 year old younger brother, Mark, a university student. John used to spend at least four hours travelling to and from Phnom Penh City to buy locks for his business. He found it physically exhausting and time consuming. John tried using the district bank branch to transfer money to his brother (Mark) to help buy the locks but faced the inconveniences of closing his business and having to complete bank forms with identification verification required for both sender and receiver. Moreover the service fee (between US\$2.00 to US\$3.00) was expensive. Using taxi intermediary services did alleviate John's difficulties but created other frustrations for Mark. 
After using mobile money services, John found it faster and more convenient to transfer money to his brother, Mark, to buy his locks. John's accessibility was enhanced as he could purchase his locks without having to close his business and making the long travel ride to Phnom Penh City

'Mobile money services helped to reduce my costs on money transfer service fee as well as transportation and meal costs for my trip to Phnom Penh city to purchase my locks. With reduced time in travelling, I can now save more time and do not require closing my business. Hence I can effectively earn more money.'

Jim, a telephone operator salesman, and his siblings often transferred money to one another to buy personal or business products. Using mobile money services further enhanced their accessibility to these products by reducing the lengthy time required to purchase them. Jim recollected how he used mobile money services to transfer money immediately to his siblings to purchase clothes.

'For example, I previously visited the clothes shop in Phnom Penh with them. But now I am here and do not have time to go to Phnom Penh. So I asked them to go there to buy new clothes for me. And I used mobile money services to transfer the money to them.' 
Reducing task complexity

Money transfer by rural bank branches incurred high transfer fees and long waiting queues for both the senders and receivers. Informants also described the frustration of travelling long distances to the nearest rural bank branch and spending time queuing up and completing complicated money transfer service forms. The process also required proof of identification for both the sender and receiver to complete the transaction. After using mobile money services, informants could immediately transfer their own available money quickly. This was done through a simplified and less complex procedure by initiating the money transfer service on their mobile phones and providing receivers with an 8 digit code to collect the money at the nearest mobile money service collection point.

Requiring to travel about $100 \mathrm{~km}$ to the nearest rural bank branch to transfer money to his poor family, Ricky, a soldier, described the complexities faced and how mobile money services made it less complicated, more convenient and cheaper.

'I used to just transfer money through bank services. They charged the fees differently and it is expensive. It costs US\$3.00 from a rural district town to a rural main town and US\$2.00 from a rural main town to a rural main town. I had to wait for long time when there were a lot of people. And I had to fill in documents. I would have to go to the nearest district town which is very far... it's about $100 \mathrm{~km}$ away. But now mobile money services are just near here (mobile money agent cash in point is about 10 minutes drive from Ricky's location). I just spend a very little short time to cash in and transfer money.' 
Susan, a hairdresser, used to transfer money to her family through a rural bank branch which was tedious and inconvenient.

'It takes so long at the bank branch where there are a lot of customers and we have to queue and wait. Then I have to fill up the documents. So it takes a lot of time. Sometimes it takes more than an hour and after I completed and filled up the documents and deposit the money I have to call the other side to my siblings. And my siblings on the other side have to go to the bank branch. And then they also queue up to wait and then fill the documents before they can take the money.... I have to spend a lot of time on my side and on the other side they have to spend a lot time...'

After using mobile money services, Susan described the mobile money service process as easier, less complicated and more convenient.

'I can now transfer my money very quickly to my family in case they need money and now I don't have to wait like before. Then I have to wait and queue at the bank to fill up documents. I took a long time. Now I don't even have to worry that if it is a Saturday or Sunday or weekdays that the banks open or not. Because I can use mobile money services all the time anytime.'

The examples of Ricky and Susan illustrate the frustrations and inconvenience in existing money transfer services within subsistence context. Indeed, the use of mobile money services brought immense benefits of convenience to the subsistence consumers by removing the lengthy queuing and service time, simplifying the process with minimal documentation requirements and reducing the long distance travelling to access the service. 


\section{Elimination of intermediation}

Informal intermediary services like bus, truck and taxi drivers in the vicinity were used but would take a couple of days for the sender's funds to reach the receiver. Moreover, these informal intermediaries had other scheduling priorities leaving the informants faced with the uncertainty of when they could be readily available and where to find them. Informants also reported their money being stolen or gone "missing" through intermediary transactions. Furthermore, informants who live in floating villages on the water either had to pay expensive transport fuel costs or hire boat drivers to first transfer money to taxi drivers waiting at the sea ports on land. Money transfers through informal intermediaries often required negotiations as prices were not displayed and not always fixed. This made pricing of goods and services for business owners extremely difficult.

Similarly after using mobile money services, informants could immediately transfer their own available money quickly without these intermediaries. This was done through a simplified and less complex procedure by initiating the money transfer service on their mobile phones and providing receivers with an 8 digit code to collect the money at the nearest mobile money service collection point. Furthermore informants and their corresponding receivers could now better control their timing and scheduling priorities.

Gordon lives in the floating village community and runs a small grocery store at his boat house. Gordon was grateful for the mobile money services that prevented a repeat of his negative experiences with taxi drivers by providing money transfer services when ordering his grocery supplies on land.

'I am afraid to send money by taxi. I had bad experience of losing some money. It is very easy now because sending money by mobile money services is safe. After experiencing 
losses through taxis, I am afraid of losing money. Now I am not afraid of loss as I can know clearly the status of my transaction from the mobile phone.'

William, a mobile phone shop owner, from the same floating village also recollected his negative experience using taxis to transfer money to pay his phone supplier for his ordered supplies and how mobile money services overcame that problem.

'With mobile money services, I could save much time and I rarely lose any supplies sent by my supplier. If I transferred money by taxi, sometimes I do not receive the correct number of supplies I paid for. But when I transfer money using mobile money services, it is very safe for me as I never lose any money. If I transfer money with the actual amount the suppliers get all of the money that I sent. And they also send the correct amount of supplies.'

\section{Second level impacts of mobile money services on social network relationships}

Interpersonal level

As a result from the change at the first level impacts on the actual physical money transfer transaction, informants experienced closer and improved relationships among their personal or business social networks. When money was urgently required but not received on time, there were physical and emotional frustrations experienced in collecting the money through other intermediaries. Unmet needs and miscommunications together with physical and emotional frustrations were significantly reduced after using mobile money services to transfer money instantly and being able to conveniently collect the money. 
The easy and convenient money transfer through mobile money services, as resolved through the first level impact, resulted in improved relationships between Ricky and his family. Before using mobile money services, travelling approximately $100 \mathrm{~km}$ to the nearest rural bank branch to transfer money and also having to wait for a long time to be served in the rural bank branch discouraged Ricky.

'When I use banks, I just don't want to transfer money and going to town. I feel very discouraged. I (also) had to spend a lot of time to wait... I felt that I didn't want to transfer money.'

With mobile money services, Ricky had easy access to transfer money at the mobile money agent about 10 minutes' drive from his location. Ricky found it easier and more convenient to transfer money to his family. His feelings became different after using mobile money services.

I feel that I want to transfer money and I think a lot more about my family... (My relationship with my family is) closer and I feel love when transferring money (using mobile money services) to my family. My family and I feel very close.'

Similarly, Mark described his frustrations when his brother (John) transferred him money to buy locks.

If my brother (John) transferred money through the taxi driver, it would take about two hours before the taxi driver arrived in Phnom Penh. The taxi driver had to call me to tell me his location and I would go and wait for him. Sometimes these taxi drivers are unreliable and bad. They do not wait for us but want us to wait for them. So before they arrived, they would call me to wait for him. So there I was waiting but the taxi driver was 
not there yet, so I had to wait for a long time... it's hot waiting under the sun. And sometimes it rains. I felt angry. Sometimes also I had to go there when it's time for my classes.'

Eventually, Mark also found it more convenient and less frustrating after using mobile money services.

'In the past, I was angry and often complained to my brother on the inconvenience and frustration to wait for taxi driver in hot and wet weather to collect money for buying the locks supply. Using mobile money services makes it easier to cash out my brother's money from the mobile money account to pay for the locks.'

Mark also believed that mobile money services improved his relationship with his brother.

'Yes it is happier. In the past when I didn't have mobile money services I felt angry with my brother because I have to waste time waiting for the taxi to collect the money. And you know the feeling of standing to wait in the heat and the rain. So I felt angry. And then I called and complained to him and then he became angry with me.'

When asked what the difference was before and after using mobile money services, Mark replied,

'Our relationship is better. Now I just call him and he transfers money to me immediately for spending. It's different from the past... he transfers money to me to support my living and support my studies.' 
John also agreed.

'Before I think we seem to be separated but after using mobile money services I find that our relationship has become much closer. And I feel as if we were living together in the same house.'

\section{Social group level}

Resulting from the first level impacts on the actual physical money transfer transaction, there were increased opportunities for informants to participate remotely in social groups located far away. Jasmine said her sister, Susan, who lives about an 8 hour drive away, used mobile money services to send over money to join an informal rotational savings group, also known as "Tong Tin" in Cambodia.

'Yes. I helped my sister to pay the money to play with Tong Tin. She is now staying in Sihanukville but she joined the Tong Tin group here in Takeo Province (about 8 hours' drive). So she had to pay the group leader every week. So the money is urgently required.'

As a result from the first level impacts on the actual physical money transfer transaction, informants expressed the satisfaction of now being able to better support family group members as part of their social obligations. With mobile money services, they could transfer extra money faster and more cheaply to family group members to support their living expenses and other circumstantial needs. 
Typical examples included respondents living away from home and sending money to support a young family member's living expenses or to support a retired senior family member's living expenses.

Nick, a farmer, is busy working about half an hour's drive from the rural district bank office. He did not have time to travel and wait in the rural district bank office to transfer money. Hence Nick clearly took advantage of mobile money services to transfer money faster and more cheaply to his daughters to support their studies in Phnom Penh.

'I send money to my daughters when I have money and when my daughters needed the money. They are students so they need to spend money for their studies.'

Informants recounted how mobile money services actually provided a fast and effective way of transferring money to their family group members or friends living far away during emergency times like paying for school fees and paying for emergency medical treatment.

Jasmine explained how mobile money services became a lifeline for her financial needs as her sister, Susan, used mobile money services to transfer money and help her out.

'At that time I had to pay for my school which was nearly due as I had to pay my other daily expenses every week and month. But suddenly I needed to pay to the teacher and I was at a loss of how to do it. I called my sister (at another town about 8 hours' drive) for help and she transferred money to me immediately. Around 10-15 minutes later I received money to pay for my school fees.'

Susan believed that mobile money services helped her family in emergency times because she did not have to worry whether her money reached them or not. 
'My mother needed to visit the doctors every 3 months. Also If I didn't transfer money to my younger sister (Jasmine) she cannot study. Without mobile money transfer services I think it is very difficult.... with mobile money services I feel very happy. I am delighted. I can transfer money immediately to them. I don't have to worry if my money arrived safely or not. With mobile money services I am sure that my money will be received by my family members ... and I don't have to worry what time the money will arrive as my money will arrive there immediately with mobile money services.'

\section{Cultural level}

Buddhism has had a long history in Cambodia and its religious traditions and practices remained dominant to date (Harris, 2012). Every year, Cambodians celebrate two big traditional festivals, namely Khmer New Year and "Chum Ben" Festival. Cambodians working in other rural towns will make every effort to return back to their hometowns for family reunions and celebrations. They celebrate by buying new clothes, buying food for family reunion meals, visiting Buddhist temples and giving family members 'gift' money to show love and respect as well as wishing them a prosperous new year ahead.

As a result from the change at the first level impacts on the actual physical money transfer transaction, informants increased their opportunities to send traditional 'gift' money through mobile phones to their family members even before making the long trip back to their hometowns as part of their cultural obligations. Furthermore, informants also transferred money faster through the mobile phones to their families to purchase new traditional festival clothes and food ingredients as part of pre-festival preparation activities. 
As a filial daughter-in-law, Shirley needed to send money to her low-income parents-inlaw to buy food ingredients. During these national festivals, they travelled to Buddhist temples and offered the purchased food ingredients to the monks as offerings to pray for good health and good life. Previously using traditional money transfer services like rural bank branches and money exchangers required her parents-in-law to arrange the boat to travel to the mainland to collect the money as soon as possible. Mobile money services allowed them to conveniently collect the money anytime without worrying about the limited collection period.

Amy's work commitments did not allow her to visit her father-in-law during these national festivals. In continuing her cultural obligations as a filial daughter-in-law, Amy also waited for relatives coming to visit her and then would pass them the money to give to her father-in-law who lived about 6-7 hours' drive away. Sometimes the relatives did not visit her, so sending money proved difficult for her. Mobile money services made it easier and faster as she could regularly send money without relying on others.

'It is very easy that I can transfer money to him very often. It is very easy and fast. I can transfer money and give the money to my father-in-law during Khmer New Year and other celebrations... I cannot or do not have time to visit him but I transfer money to him very often like Khmer New Year, Chinese New Year, Chum Ben Festival and the rainy season festival which is the Buddhist celebration for the rainy season.'

Charlie is a border immigration policeman and his busy work commitments prevented him from travelling back to visit his family to celebrate all the festive seasons together with them. Using mobile money services ensured that he was still able to fulfil his cultural obligations while not being there. 
'It depends on my work. If I have a lot of work, it means I am very busy and I cannot go (back to the hometown). If I am free I will visit them and celebrate together. But for Khmer New Year I cannot go but I send money to them instead of my presence.'

However Susan leveraged on mobile money services to send money immediately to her siblings prior to the festive celebrations. She did not have to worry whether the money safely reached them.

'I transferred money to my younger siblings before Khmer New Year for them to buy new clothes for the festival. They could buy the new stuff before Khmer New Year.'

Rather than traditional 'gift' money, some informants used mobile money services to top up phone credits for their friends or business partners. Using mobile money services became a modern and creative way to bless one another for the new year ahead or on other special occasions. Topping up their friends' mobile phone also became a festive gift to affirm their friendship. Practically this gave them more air time to chat socially with one another.

When asked if she gave cash as gift money to her friends during Chinese New Year, Lynn responded,

'No I did the phone top up for them... only to a few close friends... using mobile money services is easier. Because if I provide the gift money to my friend I don't know what do they use it for. But if I do the phone top up for them they can use extra phone credit gifts to call me.'

Jim also found mobile money services an effective way of blessing his network of rural phone shop dealers during Chinese New Year and Khmer New Year, especially the dealers who lived in the remote rural district towns. 
'For the dealers who are deep in rural town or distant areas, I used mobile money services to top up their mobile phone credits during Khmer New Year and Chinese New Year.'

Jim described it as a good gesture wishing them well for the new year ahead and to build stronger relationships with his dealers. It was also an excellent way of encouraging them and letting them know that he sincerely cared about them.

Another interesting cultural observation involved Buddhist monks who travelled outside of their monastery temples every morning to approach the public for monetary or food donations. On some occasions, they might purchase phone top-up scratch cards at mobile phone shops or grocery shops. However if Buddhist monks were seen too often near shops, the public might think they are contradicting their religious beliefs of abstaining from worldly entertainments and pleasures. With mobile money services, these Buddhist monks could now top up phone credits inside their temple compounds without being seen buying the scratch cards and getting misunderstood by the public. Buddhist monks also used mobile money accounts to safe-keep their "hard-earned" monetary donations. 


\section{Discussion}

Using the example of Cambodia, this paper extends from previous mobile money impact studies, along with the extant social capital and subsistence marketplaces literature, to identify the impacts of mobile money services on marketing interactions. This paper specifically focuses on (1) the actual physical money transfer transactions as part of marketing exchange activities and subsequently (2) the social network relationships in relation to CWB. The findings indicate mobile money as a financial service offering with attributes that impact transaction exchange disparities within the marketing exchange activities (Viswanathan, 2007). This leads to increased opportunities to access resources, support, involvement and social networks as part of CWB (Anderson, et al., 2013).

This paper has identified the impacts of mobile money services at two distinct levels. Figure 1 illustrates the mobile money services change process conceptual model that shows the first level impacts on the actual physical money transfer transaction, more specifically around the safety, convenience and speed of the transaction exchange, and subsequently the second level impacts on the social network relationships resulting from the change at the first level impacts. Table 4 summarises the paper's key contributions within the literature and maps these contributions in line with existing theoretical constructs/dimensions of CWB. Service offerings with these attributes can potentially contribute towards consumer well-being in subsistence marketplaces. 
Figure 1 Mobile Money Services Change Process Conceptual Model

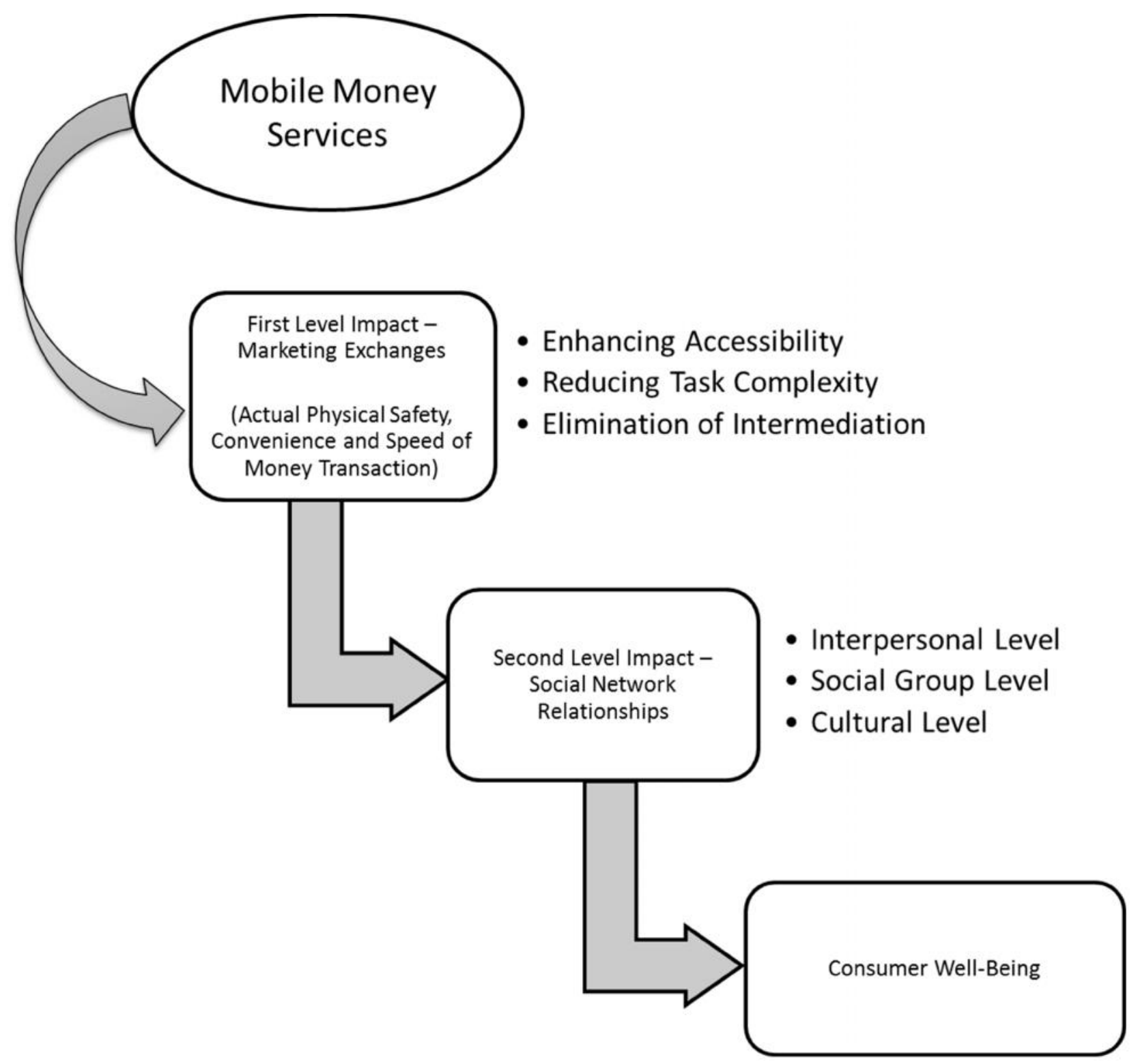


Table 4 Summary of Key Contributions Within The Literature

\begin{tabular}{|c|c|c|c|}
\hline $\begin{array}{l}\text { Themes } \\
\text { identified }\end{array}$ & Literature & Key contributions & $\begin{array}{l}\text { Mapping to existing theoretical } \\
\text { constructs/ dimensions of CWB } \\
\text { (Anderson, et al., 2013) }\end{array}$ \\
\hline $\begin{array}{l}\text { Enhancing } \\
\text { accessibility } \\
\text { (Marketing } \\
\text { exchanges) }\end{array}$ & $\begin{array}{l}\text { Shortage or unavailability of } \\
\text { products in subsistence } \\
\text { marketplaces (Chikweche \& } \\
\text { Fletcher, 2010) } \\
\text { Mobile money services as a } \\
\text { convenient single point of access } \\
\text { to mobilise various savings } \\
\text { portfolios (Morawczynski, 2011) }\end{array}$ & $\begin{array}{l}\text { Mobile money services create } \\
\text { enhanced accessibility } \\
\text { opportunities to purchase } \\
\text { products previously not available. }\end{array}$ & $\begin{array}{l}\text { Access } \\
\text { Better decision making }\end{array}$ \\
\hline $\begin{array}{l}\text { Reducing task } \\
\text { complexity } \\
\text { (Marketing } \\
\text { exchanges) }\end{array}$ & $\begin{array}{l}\text { Marketing exchange activities } \\
\text { having uncertainty, lack of } \\
\text { control and complexity } \\
\text { (Viswanathan, 2007) }\end{array}$ & $\begin{array}{l}\text { Description of money transfer } \\
\text { transactions through rural bank } \\
\text { services adds to nature of } \\
\text { marketing exchanges } \\
\text { Mobile money services impact the } \\
\text { safety, convenience and speed of } \\
\text { the actual physical transaction } \\
\text { exchange }\end{array}$ & $\begin{array}{l}\text { Access } \\
\text { Better decision making }\end{array}$ \\
\hline
\end{tabular}




\begin{tabular}{|c|c|c|c|}
\hline $\begin{array}{l}\text { Themes } \\
\text { identified }\end{array}$ & Literature & Key contributions & $\begin{array}{l}\text { Mapping to existing theoretical } \\
\text { constructs/ dimensions of CWB } \\
\text { (Anderson, et al., 2013) }\end{array}$ \\
\hline $\begin{array}{l}\text { Elimination of } \\
\text { intermediation } \\
\text { (Marketing } \\
\text { exchanges) }\end{array}$ & $\begin{array}{l}\text { Marketing exchange activities } \\
\text { having uncertainty, lack of } \\
\text { control and complexity } \\
\text { (Viswanathan, 2007) }\end{array}$ & $\begin{array}{l}\text { Description of money transfer } \\
\text { transactions through informal } \\
\text { intermediaries adds to nature of } \\
\text { marketing exchanges } \\
\text { Mobile money services changing } \\
\text { transaction exchange activity and } \\
\text { eliminating associated } \\
\text { inconveniences and security risks } \\
\text { through informal intermediaries }\end{array}$ & $\begin{array}{l}\text { Access } \\
\text { Better decision making }\end{array}$ \\
\hline $\begin{array}{l}\text { Interpersonal level } \\
\text { (Social network } \\
\text { relationships) }\end{array}$ & $\begin{array}{l}\text { The role of the social networks in } \\
\text { navigating subsistence } \\
\text { marketplaces (Viswanathan, } \\
\text { Sridharan, et al., 2010) } \\
\text { The importance of product } \\
\text { performance and social networks } \\
\text { in influencing subsistence } \\
\text { consumers to purchase products } \\
\text { or services (Chikweche \& } \\
\text { Fletcher, 2010) } \\
\text { Mobile money services maintain } \\
\text { social links but weakened social } \\
\text { network relations (Morawczynski, } \\
\text { 2009) }\end{array}$ & $\begin{array}{l}\text { Confirms the application of mobile } \\
\text { money services embedded within } \\
\text { social network relationships and } \\
\text { reducing transaction exchange } \\
\text { challenges to improve } \\
\text { interpersonal relationships }\end{array}$ & $\begin{array}{l}\text { Consumer involvement } \\
\text { Respect } \\
\text { Support } \\
\text { Social networks }\end{array}$ \\
\hline
\end{tabular}




\begin{tabular}{|c|c|c|c|}
\hline $\begin{array}{c}\text { Themes } \\
\text { identified }\end{array}$ & Literature & Key contributions & $\begin{array}{l}\text { Mapping to existing theoretical } \\
\text { constructs/ dimensions of CWB } \\
\text { (Anderson, et al., 2013) }\end{array}$ \\
\hline $\begin{array}{l}\text { Social group level } \\
\text { (Social network } \\
\text { relationships) }\end{array}$ & $\begin{array}{l}\text { Subsistence consumers focus on } \\
\text { satisfying family rather than } \\
\text { individual needs (Ruth \& Hsiung, } \\
\text { 2007) } \\
\text { Mobile money services as a safer, } \\
\text { easier and more convenient way } \\
\text { of mobilizing financial assets to } \\
\text { support rural families in times of } \\
\text { great need (Morawczynski, 2009) }\end{array}$ & $\begin{array}{l}\text { Adds insights into the challenges and } \\
\text { inconveniences faced by } \\
\text { subsistence consumers to support } \\
\text { family members } \\
\text { Mobile money services increase } \\
\text { opportunities to participate in } \\
\text { social groups previously not } \\
\text { locally or conveniently available } \\
\text { Mobile money services increase } \\
\text { access/opportunities to support } \\
\text { family group well-being }\end{array}$ & $\begin{array}{l}\text { Consumer involvement } \\
\text { Respect } \\
\text { Support } \\
\text { Social networks }\end{array}$ \\
\hline $\begin{array}{l}\text { Cultural level } \\
\text { (Social network } \\
\text { relationships) }\end{array}$ & $\begin{array}{l}\text { Gift giving offered through festival } \\
\text { seasons maintains family } \\
\text { obligations and enhances social } \\
\text { network relationships (Joy, 2001; } \\
\text { Tynan, et al., 2010) } \\
\text { Consumer behaviour within social } \\
\text { network relationships guided by } \\
\text { cultural customs, values, and } \\
\text { beliefs (Arnould \& Wallendorf, } \\
\text { 1994) }\end{array}$ & $\begin{array}{l}\text { Mobile money services enhance the } \\
\text { gift giving behaviours in a more } \\
\text { creative and practical way as part } \\
\text { of cultural/religious activities in } \\
\text { maintaining social network } \\
\text { relationships } \\
\text { Mobile money services } \\
\text { reduce/remove inconveniences to } \\
\text { increase opportunities for cultural } \\
\text { pre-activity preparations and } \\
\text { practices to fulfil cultural } \\
\text { obligations }\end{array}$ & $\begin{array}{l}\text { Consumer involvement } \\
\text { Respect } \\
\text { Support } \\
\text { Social networks }\end{array}$ \\
\hline
\end{tabular}




\section{Mobile money services and marketing exchanges}

\section{Enhancing accessibility}

This paper confirms previous research noting that subsistence marketplaces experience a shortage or unavailability of products (Chikweche \& Fletcher, 2010). Building from previous studies showing mobile money services as a convenient single point of access to mobilise various savings portfolios (Morawczynski, 2011), this paper illustrates how mobile money services can also be used to create enhanced accessibility opportunities to purchase products previously not available. Mobile money services serve as a transaction channel to enhance accessibility by leveraging on existing social networks to enable product purchase irrespective of location. This significantly reduces the lengthy time and inconvenience of transferring money to families or friends with access to purchase the required products.

Building upon social resources theory, this paper reinforces the notion that mobile money as a service offering for subsistence marketplaces (1) Increases the accessibility of resources through direct and indirect social networks; and (2) Increases mobilisation of resources among social networks (Lin, 1999; Viswanathan, Sridharan, et al., 2010).

\section{Reducing task complexity}

This paper builds from previous studies describing transaction exchanges as one aspect of dayto-day life having uncertainty, lack of control and complexity when examining the marketing exchange activities in marketing interactions (Viswanathan, 2007). 
This paper adds to the nature of marketing exchanges in subsistence marketplaces (Viswanathan, 2007), specifically relating to money transfer transactions between the sender and receiver. To fully complete the transaction exchanges, subsistence consumers rely heavily on rural bank branch networks which are time-consuming, requiring completion of complex forms and having complicated identification procedures for the sender and receiver. It illustrates mobile money services as a service offering impacting the safety, convenience and speed of the actual physical transaction exchange. Instead of using rural bank branch networks, subsistence consumers bypassed them by using their own mobile phones as alternative channels to transfer money in a more secured and convenient way.

\section{Elimination of intermediation}

To fully complete the transaction, subsistence consumers also traditionally relied heavily on intermediary channels across land and/or water with limited flexibility and inconvenient delivery/scheduling times for the transaction sender and receiver. Such transaction exchanges are also unpredictable with prices not displayed and subjected to negotiations.

Building from previous studies of examining the marketing exchange activities within marketing interactions in subsistence marketplaces (Viswanathan, 2007), this paper adds to the marketing exchange nuances highlighting mobile money services changing subsistence marketplaces transaction exchange activity. It shows mobile money services eliminating the associated inconveniences and security risks through informal intermediaries while increasing the transaction exchange predictability, timing and flexibility back to the convenience and control of the transaction sender and receiver. 


\section{Mobile money services and social network relationships}

\section{Interpersonal level}

By understanding the effects of a service offering on social network relationships in subsistence marketplaces, this paper confirms the application of mobile money services embedded within social network relationships (Sridharan \& Viswanathan, 2008) which is an important feature in subsistence marketplaces. The findings go beyond previous studies of the social networks' role in navigating subsistence marketplaces (Viswanathan, Sridharan, et al., 2010) and understanding the importance of product performance and social networks in influencing subsistence consumers to purchase products or services (Chikweche \& Fletcher, 2010).

Before mobile money services, subsistence consumers encounter relational frictions and tensions due to existing service offerings or circumstances not adequately addressing the inconvenience and safety challenges of the actual physical money transfer transaction. Contrary to that of Morawczynski (2009), this paper shows mobile money services serving as a tool in reducing these transaction exchange challenges experienced by subsistence consumers and overcoming the physical separation and distance between the sender and receiver. Hence this leads to enhanced family/social ties and inter-personal relationships. 


\section{Social group level}

Interestingly, this paper reveals mobile money services acting as a bridge to enable an opportunity to participate in social groups previously not locally or conveniently available. This also demonstrates how mobile money impacts social group factors by overcoming the physical separation or distance barrier. This phenomenon highlights the mobile money service offering as part of enhancing the access and social network dimensions (Anderson, et al., 2013) of consumer well-being.

The paper illustrates the role of the subsistence consumers in supporting other family group members' living expenses and other circumstantial/emergency needs. This is consistent with previous findings on subsistence consumers focusing on satisfying family rather than individual needs (Ruth \& Hsiung, 2007). However, this paper adds further insights into the physical separation challenges and inconveniences faced by subsistence consumers to send money back to support family members. It then shows how mobile money services overcome the physical separation challenges and conveniences by increasing access/opportunities for subsistence consumers to support family group well-being. Mobile money services also enable family members to be able to send extra money due to savings from reduced transfer fees. Hence this reinforces mobile money services as an innovative "emergent solution" (Viswanathan, et al., 2012) to help subsistence consumers spend less and free up resources to increase individual, family and social group well-being in subsistence marketplaces (Ruth \& Hsiung, 2007). 


\section{Cultural level}

This paper emphasises the important role of gift giving within subsistence marketplaces. The importance of Cambodian gift giving practice is consistent with previous studies showing how gift giving offered traditionally through festival seasons maintains family obligations and enhances social network relationships (Joy, 2001; Tynan, et al., 2010). It also confirms previous findings on maintaining cultural and religious traditions/practices from the centrality of 1-1 social interactions in any circumstances (Viswanathan, 2007).

This study shows how mobile money services enhance the gift giving behaviours among subsistence consumers in a more creative and practical way to be more actively involved in cultural and religious activities in maintaining social network relationships. Furthermore, mobile money services increase opportunities to maintain and even enhance the subsistence consumers' cultural and religious activity needs as part of the marketing interactions phenomena even though they are physically separated by locality distance from the cultural and religious activities themselves.

There is a need to better understand cultural distinctions and oral traditions (Viswanathan \& Rosa, 2007) when shaping subsistence consumers' responsiveness within the marketing interactions. Cultural and religious activities for subsistence consumers in Cambodia encompass pre-activity preparations (like purchasing cultural clothes and preparing culture-special food ingredients) and practices (like 'gift' money, Buddhist monks, religious site visits or food offerings). In helping subsistence consumers reduce/remove inconveniences, as seen from the first level impacts on the actual physical money transactions, mobile money services increase opportunities to accomplish these cultural preparations and practices. 
By doing so, this fulfils one's cultural obligations and also enhances the celebrative nature of these cultural and religious activities in subsistence marketplaces. This reinforces the need to incorporate within marketing interactions the layering of beliefs and value-systems (Craig \& Douglas, 2006), centred around the social and cultural contexts (Singh, 2004). This increases the effects of a service offering by contributing towards consumer well-being in subsistence marketplaces.

\section{Limitations of mobile money services}

Although this paper positions mobile money services mostly as a panacea of problems in subsistence marketplaces, there are notable limitations to this service offering. Mobile money services are not always perfect transaction exchanges as customers will experience system errors and phone network connectivity problems resulting in incomplete transaction exchanges.

Cambodia's dual currency can possibly deter mobile money services especially in transaction exchanges for micro-enterprises, most notably if the exchange rate between the US Dollar and the Cambodian Khmer Riel prove unfavourable. Business suppliers are usually based in Phnom Penh City and tend to transact in US dollars. On the other hand, micro-enterprises in rural areas tend to transact in the Cambodian Khmer Riel currency. A micro-entrepreneur orders the goods and pays the business supplier in Khmer Riel using mobile money services. The business supplier prefers to cash out from the mobile money agent in US dollars. Such scenarios may prove unfavourable as subsistence consumers may lose a small percentage of revenue/income through a low exchange rate. 
Mobile money services can be counter-productive, depending on one's level of cultural beliefs/values and circumstantial commitments. The notion of fulfilling one's cultural obligations by sending 'gift' money home faster but without travelling back to be with their families for the celebrations can sometimes alter or weaken social networks and family ties within the marketing interactions. This is confirmed by Morawczynski (2009) who noted the effects of mobile money services in Kenya played a symbolic role in maintaining social networks but resulted in complaints about senders making fewer visits back to family members.

Although not a major finding in this paper, one potential "dark side" of convenience is having the ability to remotely participate in social betting groups using mobile money services. This was highlighted by one rural participant who was able to participate in World Cup Soccer betting in Phnom Penh City by transferring the betting money through mobile money services.

Informal intermediaries will also be disadvantaged as mobile money services allow subsistence consumers to bypass them. This will consequently result in less transaction exchanges for them and ultimately a portion of their income earning opportunities reduced.

The current mobile money service offering in Cambodia is only available in English as the language settings for Cambodian mobile phone models cannot be set to the local Khmer language which is predominantly understood by the majority of Cambodians in rural areas. While step-by-step instruction procedures in Khmer language and local assistance by mobile money agents are provided, this may still be difficult to use for extremely low-literate or visually impaired subsistence consumers. 


\section{Conclusions and future directions for research}

The paper illustrates the use of technology-based service offerings such as mobile money to reduce marketing exchange disparities and increase opportunities to access resources, support, involvement and social networks. Within the marketing interactions are unique social and cultural contexts with varied needs which can affect CWB in subsistence marketplaces. Such service offerings gain greater market acceptance and penetration when positioned appropriately within the social and cultural contexts and used effectively to enhance the marketing exchanges and interactions of subsistence individuals, communities or businesses.

Policy makers, financial institutions and technology service providers can draw from these insights to formulate inclusive growth strategies and develop innovative service offerings through mobile phone technology to enhance CWB in subsistence marketplaces. Insights on how mobile money services enhanced accessibility to purchase products and reduce task complexities within the marketing exchange activities demonstrate the need for effective policy implementation to enable an inclusive electronic platform using mobile phones suitable for subsistence consumers in commerce or business trading activities. This will also enable the informal sector to gain access linkages virtually to other formal or informal economies (Viswanathan, et al., 2012). Insights illustrating mobile money services making an impact on social network relationships can inform policy makers on the need to enable an environment whereby the design of financial products and services incorporates social group dynamics rather than individual behaviours. One such example is to enable co-joint holders and group trust funds for mobile money accounts to better facilitate existing social self-help group participations and family/communal group support. 
This paper can be viewed as exploratory. Further studies can possibly construct suitable CWB measures for technology-based service offerings like mobile money services and test it on a larger sample size within subsistence marketplaces. As this study was conducted in Cambodia, similar studies can be conducted in other countries within the same region like Myanmar, Thailand and Vietnam to initiate cross-country comparison research studies. This will bring immense benefits in rolling out value-added products and services through mobile phones to other subsistence marketplaces.

Another research opportunity is to further understand how the marketing interactions of micro and small enterprises in subsistence marketplaces can be better-served through technology-based service offerings like mobile money services. By doing so would shed further light in understanding what suitable mobile-based products and services can be developed to reduce operational costs, obtain higher profit margins and gain higher market access opportunities for micro and small enterprises in subsistence marketplaces.

The question of how mobile money services can enhance subsistence consumers' financial capability behaviours and how microfinance institutions can effectively use mobile money as a service offering for driving financial inclusion (Vong, Fang, \& Insu, 2012) in subsistence marketplaces should also be further investigated. 


\section{References}

Abraham, R. (2007). Mobile Phones and Economic Development: Evidence from the Fishing Industry in India. Information Technologies and International Development, 4(1), 5-17.

Anderson, L., Ostrom, A. L., Corus, C., Fisk, R. P., Gallan, A. S., Giraldo, M., et al. (2013). Transformative Service Research: An Agenda for The Future. Journal of Business Research, 66(8), 1203-1210. doi: http://dx.doi.org/10.1016/j.jbusres.2012.08.013

Angrosino, M. (2007). Doing Ethnographical and Observational Research. In U. Flick (Ed.), The SAGE Qualitative Research Kit. London, UK: SAGE Publications Ltd.

Arnould, E. J., \& Wallendorf, M. (1994). Market-Oriented Ethnography: Interpretation Building and Marketing Strategy Formulation. Journal of Marketing Research, 31(4), 484-504. doi: $10.2307 / 3151878$

Bagozzi, R. P. (1975). Marketing as Exchange. Journal of Marketing, 39(4), 32-39. doi: $10.2307 / 1250593$

Bello-Bravo, J., Diaz, R., Venugopal, S., Viswanathan, M., \& Pittendrigh, B. R. (2010). Expanding the Impact of Practical Scientific Concepts for Low-literate Learners through an Inclusive and Participatory Virtual Knowledge Ecosystem. Journal of the World Universities Forum, 3(4), 147-164.

BMI. (2012). Cambodia \& Laos Telecommunications Report - Q4 2012 (pp. 1-93). London, United Kingdom, London: Business Monitor International.

Burroughs, J. E., \& Rindfleish, A. (2011). What Welfare? On the Definition and Domain of Transformative Consumer Research and the Foundational Role of Materialism. In D. G. Mick, S. Pettigrew, C. Pechmann \& J. L. Ozanne (Eds.), Transformative Consumer Research for Personal and Collective Well-Being (pp. 245-262). New York, USA: Taylor $\&$ Francis.

Chen, M. A. (2007). Rethinking the Informal Economy: Linkages with the Formal Economy and the Formal Regulatory Environment: DESA Working Paper No. 46, Department of Economic and Social Affairs, United Nations.

Chikweche, T., \& Fletcher, R. (2010). Understanding Factors That Influence Purchases in Subsistence Markets. Journal of Business Research, 63(6), 643-650. doi: 10.1016/j.jbusres.2009.04.024

Chopra, S., Dwivedi, R., \& Sherry, M. A. (2013). Leveraging Technology Options for Financial Inclusion in India. International Journal of Asian Business and Information Management (IJABIM), 4(1), 10-20. doi: 10.4018/jabim.2013010102

Craig, C. S., \& Douglas, S. P. (2006). Beyond National Culture: Implications of Cultural Dynamics for Consumer Research. International Marketing Review, 23(3), 322-342. doi: 10.1108/02651330610670479

Dahlberg, T., Mallat, N., Ondrus, J., \& Zmijewska, A. (2008). Past, Present and Future of Mobile Payments Research: A Literature Review. Electronic Commerce Research \& Applications, 7(2), 165-181.

Davis, E. W. (2009). Treasures of the Buddha: Imagining death and life in contemporary Cambodia. 3362007 Ph.D., The University of Chicago, Ann Arbor. Retrieved from http://search.proquest.com/docview/305062096?accountid=13552. ProQuest

Dissertations \& Theses Full Text database.

Davis, R., \& Dart, J. (2005). The 'Most Significant Change' (MSC) Technique - A Guide To Its Use. Retrieved from http://www.mande.co.uk/docs/MSCGuide.htm 
Demirguc-Kunt, A., \& Klapper, L. (2012). Measuring Financial Inclusion: The Global Findex Database: World Bank Policy Research Paper 6025, The World Bank, USA.

Dewan, S. M. (2010, 1-3 December, 2010). Past, Present and Future of M-Banking Research: A Literature Review. Paper presented at the ACIS 2010 Proceedings, Paper 84, Brisbane, Australia

Diniz, E. H., Albuquerque, J. P. d., \& Cernev, A. K. (2011). Mobile Money and Payment: A Literature Review Based On Academic and Practitioner-Oriented Publications (20012011). Paper presented at the Proceedings of SIG GlobDev Fourth Annual Workshop, Shanghai, China.

Donavan, K. (2012). Chapter 4 - Mobile Money for Financial Inclusion. In T. Kelly, N. Friederici, M. Minges \& M. Yamamichi (Eds.), 2012 Information and Communications for Development-Maximizing Mobile (pp. 61-74). Washington DC, USA: The World Bank Group.

Donner, J. (2006). The Use of Mobile Phones by Microentrepreneurs in Kigali, Rwanda: Changes to Social and Business Networks. Information Technologies and International Development, 3(2), 3-19.

Donner, J., \& Tellez, C. A. (2008). Mobile Banking And Economic Development: Linking Adoption, Impact, And Use. Asian Journal of Communication, 18(4), 318-332.

Duffy, J., \& Ochs, J. (1999). Emergence of Money as a Medium of Exchange: An Experimental Study. The American Economic Review, 89(4), 847-877. doi: 10.2307/117162

Duncombe, R., \& Boateng, R. (2009). Mobile Phones and Financial Services in Developing Countries: A Review of Concepts, Methods, Issues, Evidence and Future Research Directions. Third World Quarterly, 30(7), 1237-1258.

FitzGerald, I., Suvannariddhi, S., \& Suphal, C. (2007). Moving Out of Poverty? Trends in Community Well-Being and Household Mobility in Nine Cambodian Villages: Cambodia Development Research Institute (CDRI).

Flick, U. (2009). An Introduction to Qualitative Research (4th ed.). London, UK: Sage Publications Inc.

Flood, D., West, T., \& Wheadon, D. (2013). Trends in Mobile Payments in Developing and Advanced Economies. Australia: Reserve Bank of Australia.

Gibbs, G. (2007). Analyzing Qualitative Data. In U. Flick (Ed.), The SAGE Qualitative Research Kit. London, UK: SAGE Publications Ltd.

GSMA. (2013a, December 9, 2013). Cambodia - Mobile Phone Network Coverage, from https://mobiledevelopmentintelligence.com/countries/KHM-cambodia\#

GSMA. (2013b, May 17, 2013). Mobile Money for The Unbanked - Deployment Tracker, from http://www.gsma.com/mobilefordevelopment/programmes/mobile-money-for-theunbanked/tracker

Hammond, A. L., Kramer, W. J., Katz, R. S., Tran, J. T., \& Walker, C. (2007). The Next 4 Billion - Market Size and Business Strategy At The Base of The Pyramid. Retrieved from http://pdf.wri.org/n4b full text lowrez.pdf

Harris, I. (2012). Buddhism In Cambodia Since 1993. In P. Sothirak, G. Wade \& M. Hong (Eds.), Cambodia: Progress and Challenges Since 1991 (pp. 320-336). Singapore: Institute of South East Asian Studies.

Heyer, A., \& Mas, I. (2010). Seeking Fertile Grounds for Mobile Money. Retrieved from http://www.pymnts.com/journal-bak/lydian-payments-journal-2010/seeking-fertilegrounds-for-mobile-money-2/

Hughes, C. (2006). The Politics of Gifts: Tradition and Regimentation in Contemporary Cambodia. Journal of Southeast Asian Studies, 37(3), 469-489. doi: 10.2307/20071787 
IFAD. (2010). Rural Poverty Report 2011. Retrieved from www.ifad.org/rpr2011/report/e/rpr2011.pdf

ITU. (2013). ITU World Telecommunication/ ICT Indicators Database. Retrieved from http://www.itu.int/en/ITU-D/Statistics/Pages/stat/default.aspx

Jack, W., \& Suri, T. (2011). Mobile Money: The Economics of M-PESA. Cambridge, Massachusetts, USA: National Bureau of Economic Research.

Joy, A. (2001). Gift Giving in Hong Kong and the Continuum of Social Ties. Journal of Consumer Research, 28(2), 239-256. doi: 10.1086/322900

Kiyotaki, N., \& Wright, R. (1989). On Money as a Medium of Exchange. Journal of Political Economy, 97(4), 927-954. doi: 10.2307/1832197

Kvale, S. (2007). Doing Interviews. In U. Flick (Ed.), The SAGE Qualitative Research Kit. London, UK: SAGE Publications Ltd.

Ledgerwood, J. (2012). Buddhist Ritual and The Reordering of Social Relations in Cambodia. South East Asia Research, 20(2), 191-206. doi: 10.5367/sear.2012.0100

Lin, N. (1999). Social Networks and Status Attainment. Annual Review of Sociology, 467-487.

Lusch, R. F., Brown, S. W., \& Brunswick, G. J. (1992). A General Framework for Explaining Internal vs. External Exchange. Journal of the Academy of Marketing Science, 20(2), 119-134. doi: 10.1007/BF02723452

Marshall, C., \& Rossman, G. B. (1999). Designing Qualitative Research (3rd ed.). California, USA: Sage Publications Inc.

Mauree, V., \& Kohli, G. (2013). The Mobile Money Revolution - Part 2: Financial Inclusion Enabler ITU-T Technology Watch Report. Geneva, Switzerland: International Telecommunications Union (ITU).

McDonald, D., Bammer, G., \& Deane, P. (2009). Research Integration Using Dialogue Methods. Canberra, Australia.: ANU E Press.

Morawczynski, O. (2009). Exploring The Usage and Impact of "Transformational" Mobile Financial Services: The Case of M-PESA in Kenya. Journal of Eastern African Studies, 3(3), 509-525. doi: 10.1080/17531050903273768

Morawczynski, O. (2011). Saving Through The Mobile: A Study of M-PESA in Kenya. In A. Ashta (Ed.), Advanced Technologies for Microfinance: Solutions and Challenges (pp. 148-164). Hershey, Pennsylvania, USA: IGI Global.

MPTC. (2012). Mobile Devices - Improving Mobile services, Especially in Regional, Rural and Remote Areas. Cambodia: Ministry of Posts and Telecommunications Cambodia.

NBC. (2010). Annual Report 2010. Cambodia: National Bank of Cambodia (NBC).

NIS. (2010). Labour Force 2007 Report Based on The Cambodia Socio-Economic Survey. Cambodia: National Institute of Statistics (NIS).

NIS. (2012). Labour Force Report - Cambodia Socio-Economic Survey Tables. Cambodia: National Institute of Statistics (NIS).

North, P. (2008). CultureShock! Cambodia A Survival Guide to Customs and Etiquette. Singapore: Marshall Cavendish International Asia Ptd Ltd.

Pancer, E., \& Handelman, J. (2012). The Evolution of Consumer Well-Being. Journal of Historical Research in Marketing, 4(1), 177-189. doi: http://dx.doi.org/10.1108/17557501211195118

Rosa, J. A. (2012). Marketing Education for the Next Four Billion: Challenges and Innovations. Journal of Marketing Education, 34(1), 44-54. doi: 10.1177/0273475311430802

Ruth, J. A., \& Hsiung, R. O. (2007). A Family Systems Interpretation of How Subsistence Consumers Manage: The Case of South Africa. In J. A. Rosa \& M. Viswanathan (Eds.), 
Product and Market Development for Subsistence Marketplaces (Vol. 20, pp. 59-87): Emerald Group Publishing Limited.

Schuman, D. (1982). Policy Analysis, Education, And Everyday Life. Lexington, MA, USA: D.C. Heath.

Seidman, I. (2006). Interviewing As Qualitative Research - A Guide For Researchers In Education and The Social Sciences (3rd ed.). New York, USA: Teachers College Press.

Singh, S. (2004). Impersonalisation of Electronic Money: Implications for Bank Marketing. International Journal of Bank Marketing, 22(7), 504-521.

Singh, S., \& Shelly, M. (2010). New Financial Services - Review of Mobile Money Transfers in the Asia-Pacific. Australia: Smart Services CRC.

Smith, M., \& Spence, R. (2011). Mobile Phones and Expanding Human Capabilities. Information Technologies and International Development, 7(3), 77-88.

Sridharan, S., \& Viswanathan, M. (2008). Marketing in Subsistence Marketplaces: Consumption and Entrepreneurship in a South Indian Context. Journal of Consumer Marketing, 25(7), 455-462.

Tobbin, P. E. (2011, 20-21 June 2011). Understanding Mobile Money Ecosystem: Roles, Structure and Strategies. Paper presented at the 2011 Tenth International Conference on Mobile Business (ICMB), Como, Italy.

Trujillo, C. A., Barrios, A., Camacho, S. M., \& Rosa, J. A. (2010). Low Socioeconomic Class and Consumer Complexity Expectations for New Product Technology. Journal of Business Research, 63(6), 538-547.

Tynan, C., Teresa Pereira Heath, M., Ennew, C., Wang, F., \& Sun, L. (2010). Self-Gift Giving in China and the UK: Collectivist versus Individualist Orientations. Journal of Marketing Management, 26(11-12), 1112-1128. doi: 10.1080/0267257X.2010.508981

Viswanathan, M. (2007). Understanding Product and Market Interactions in Subsistence Marketplaces: A Study in South India. In J. A. Rosa \& M. Viswanathan (Eds.), Product and Market Development for Subsistence Marketplaces (Vol. 20, pp. 21-57): Emerald Group Publishing Limited.

Viswanathan, M., Gajendiran, S., \& Venkatesan, R. (2008). Enabling Consumer and Entrepreneurial Literacy in Subsistence Marketplaces (Vol. 12). Dordrecht: Springer Netherlands, Dordrecht.

Viswanathan, M., \& Rosa, J. A. (2007). Product and Market Development for Subsistence Marketplaces: Consumption and Entrepreneurship Beyond Literacy and Resource Barriers. In J. A. Rosa \& M. Viswanathan (Eds.), Product and Market Development for Subsistence Marketplaces (Vol. 20, pp. 1-17): Emerald Group Publishing Limited.

Viswanathan, M., Rosa, J. A., \& Ruth, J. A. (2010). Exchanges in Marketing Systems: The Case of Subsistence Consumer-Merchants in Chennai, India. Journal of Marketing, 74(3), 117.

Viswanathan, M., Seth, A., Gau, R., \& Chaturvedi, A. (2007). Doing Well by Doing Good: Commercial Success Through Social Good in Subsistence Markets", Best Paper Proceedings, Academy of Management Meeting, Philadelphia, August.

Viswanathan, M., Sridharan, S., Gau, R., \& Ritchie, R. (2009). Designing Marketplace Literacy Education in Resource-Constrained Contexts: Implications for Public Policy and Marketing. Journal of Public Policy \& Marketing, 28(1), 85-94. doi: 10.1509/jppm.28.1.85

Viswanathan, M., Sridharan, S., \& Ritchie, R. (2010). Understanding Consumption and Entrepreneurship in Subsistence Marketplaces. Journal of Business Research, 63(6), 570581. doi: http://dx.doi.org/10.1016/j.jbusres.2009.02.023 
Viswanathan, M., Sridharan, S., Ritchie, R., Venugopal, S., \& Jung, K. (2012). Marketing Interactions in Subsistence Marketplaces: A Bottom-Up Approach to Designing Public Policy. Journal of Public Policy \& Marketing, 31(2), 159-177. doi: 10.1509/jppm.11.049

Vong, J., Fang, J., \& Insu, S. (2012). Delivering Financial Services through Mobile Phone Technology: A Pilot Study on Impact of Mobile Money Service on Micro-Entrepreneurs in Rural Cambodia. International Journal of Information Systems and Change Management, 6(2), 177-186. doi: 10.1504/IJISCM.2012.051152

WBG. (2012a). The Little Data Book on Financial Inclusion 2012. Washington D.C., USA: The World Bank Group.

WBG. (2012b). The World Bank Group World dataBank - World Development Indicators (WDI) \& Global Development Finance (GDF). Retrieved from http://data.worldbank.org/country/

WBG. (2013). The Little Data Book on Information and Communication Technology 2013. Washington DC, USA: World Bank Group.

Weidner, K. L., Rosa, J. A., \& Viswanathan, M. (2010). Marketing to Subsistence Consumers: Lessons from Practice. Journal of Business Research, 63(6), 559-569. doi: 10.1016/j.jbusres.2009.02.022

WING. (2013a). WING Mobile Money Services Registration Data. Cambodia: WING Money Cambodia.

WING. (2013b). WING Mobile Money Services Transaction Data. Cambodia: WING Money Cambodia.

Wong, P., Hogg, M. K., \& Vanharanta, M. (2012). Consumption Narratives of Extended Possessions and the Extended Self. Journal of Marketing Management, 28(7-8), 936-954. doi: 10.1080/0267257X.2012.698632

Woolcock, M. (1998). Social Capital and Economic Development: Toward a Theoretical Synthesis and Policy Framework. Theory and Society, 27(2), 151-208. doi: 10.1023/A:1006884930135

Wrigley, R. (2006). Learning from Capacity Building Practice: Adapting The 'Most Significant Change' (MSC) Approach to Evaluate Capacity Building Provision by CABUNGO in Malawi: Praxis Paper No. 12, International NGO Training and Research Centre (INTRAC). 